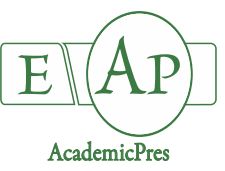

Zaier H et al. (2021)

Notulae Botanicae Horti Agrobotanici Cluj-Napoca

Volume 49, Issue 1, Article number 12125

DOI: $10.15835 /$ nbha49112125

Research Article

\title{
Filamentous fungi isolated from Tunisian olive mill wastes: use of solid-state fermentation for enzyme production
}

\author{
Hanen ZAIER ${ }^{1 *}$, Sameh MAKTOUF², Sevastianos ROUSSOS ${ }^{3}$, \\ Ali RHOUMA ${ }^{1}$ \\ ${ }^{1}$ Laboratory of Integrated Olive Production, Olive Tree Institute, Hedi Karray Street, P.O. Box 208, 2080, Ariana, Tunisia; \\ hanen_zaer@yahoo.fr (*correspondingauthor); ali.rouma@gmail.com \\ ${ }^{2}$ Laboratory of Sustainability of Olive Growing in Semi-Arid and Arid Regions: Improvement of Olive Productivity and Product \\ Quality, Olive Tree Institute, Sfax, Tunisia; maktoufsameh@yahoo.fr \\ ${ }^{3}$ Aix Marseille University, Avignon University, CNRS, IRD, IMBE, Marseille, \\ France; sevastianos.roussos@imbe.fr
}

\begin{abstract}
Olive mill wastewaters and olive cake are effluents generated during olive oil production process. They represent a major disposal and potentially severe pollution problem for the industry, also promising source of substances of high value. The aim of this study is the valorization of olive mill wastes (OMWW, olive cake, olive twigs and leaves) to produce enzymes with high industrial and biotechnological potential, by the solidstate fermentation technique (SSF), from isolated fungi present in olive mill wastewater and olive cake. A total of 47 strains were isolated and purified from these two residues. The metabolic potential of isolated strains was study by testing the hydrolytic enzymes activities of lipase, protease, amylase, cellulase, invertase, phytase and tannase on agar plate media containing different substrate. The monitoring of SSF has shown that the metabolic activity of these strains is extremely rapid using this technique. Our fungi collection contains a diversity of strains capable to producing a variety of enzymes of biotechnological interest.
\end{abstract}

Keywords: biotechnological applications; enzymes; fungi; olive oil wastes; solid-state fermentation (SSF); valorization

\section{Introduction}

Food industries produce a large volume of solid and liquid residues, which represent disposal and potential environmental pollution problem (Fernández-Bolaños et al., 2006). Likewise, olive oil production, one of the foremost agro-food industries in Mediterranean countries such as Tunisia. The manufacturing process of olive oil production yields enormous quantities of two byproducts depending on the production system adopted: olive cake (OC) and olive mill wastewater (OMWW) (Nefzaoui, 1995). These two wastes are hazardous to the environment; mainly for their high organic load and chemical composition that renders them resistant to degradation (Cegarra et al., 2006; Morillo et al., 2009). Therefore, Tunisia is the most important olive-growing country in the southern Mediterranean with the average production of olive oil is over the last

Received: 21 Oct 2020. Received in revised form: 26 Nov 2020. Accepted: 03 Dec 2020. Published online: 04 Jan 2021.

From Volume 49, Issue 1, 2021, Notulae Botanicae Horti Agrobotanici Cluj-Napoca journal will use article numbers in place of the traditional method of continuous pagination through the volume. The journal will continue to appear quarterly, as before, with four annual numbers. 
10 years (2006-2016) at 176000 tones with a minimum of 70000 tones and a maximum of 340000 tones (ONH, 2016). The exports of olive oil are the leading agricultural exports and represent $40 \%$ of all, in 2015 Tunisia exported 312,000 tons of olive oil out of the 340,000 produced (ONH, 2018). However, the increase in olive production and olive oil will generate much larger quantities of these by-products. In this way, the pollution increases over the years and the search for an adequate treatment system becomes imperative (Benyahia and Zein, 2003).

Several disposal methods have been proposed and mainly include physico-chemical treatments (decantation with lime and/or chemical oxidation, incineration; ultrafiltration and reverse osmosis) (Niaounakis and Halvadakis, 2006; Arvanitoyannis et al., 2007), agronomic uses for fertilization-irrigation (Altieri and Esposito, 2008) and biological technologies (aerobic or anaerobic bioreactors, composting) (Ramond et al., 2013). The different types of treatment currently used have been only able to partly solve this problem. Indeed, most of the proposed methods remain inefficient and even limited. Current trends should focus on the integration of various technologies to treat and valorize these effluents, but at a low cost (Hafidi et al., 2005).

This would therefore, require the production of added value that will cover the extra costs generated by the application of these new technologies. Innovative biological processes, which exploit the metabolic flexibility of strains of filamentous fungi that naturally survive in olive mill waste water, and olive cake, remain par excellence the least costly processes, perfectly meeting the problem posed in the olive sector. In addition, research on filamentous fungi has already acquired great interest, mainly in the production of enzymes used in industrial processes (Maheshwari et al., 2000; Hassouni et al., 2006 a, b). Therefore, some authors described fungi biodiversity from oleic ecosystems and screened their enzymatic potential activities for biotechnological use (Romo-Sánchez et al., 2010; Baffi et al., 2012). In fact, enzymes are biological catalysts that speed up biochemical reactions in living organisms, and which can be extracted from cells and then used to catalyze a wide range of commercially important processes (Robinson, 2015). They have found application in many industries including pulp and paper, leather, detergents and textiles, pharmaceuticals, chemical, biofuels, food and animal feed, among others. In all areas of application, enzymes are used to effectively facilitate transformations or to replace traditional chemical processes making them cleaner with less impact on the environment (Adrio and Demain, 2014; Lobedanz et al., 2016).

Microbial enzymes are the most requested because of their ease of production and extraction, and owing to their special characteristics such as stability in large range of temperature and $\mathrm{pH}$ (Nigam, 2013). Therefore, microorganisms, as enzymes source, are of much attention because they can be grown economically and are amenable to genetic modification. Researchers are looking for new microbial strains in order to produce different enzymes which fulfill the current industrial requirements (Sanchez and Demain, 2017). Among the processes used for enzyme production, Solid-state fermentation (SSF) is attractive because of its numerous advantages, particularly the possibility of using solid agricultural and agro-industrial residues as a medium for microbial growth (Pandey et al., 2001; Panagiotou et al., 2003; Rodriguez Couto and Sanroman, 2006). Thus, SSF has built up credibility in recent years in biotech industries due to its potential applications in the production of biologically active secondary metabolites, apart from feed, fuel, food, industrial chemicals and pharmaceutical products and has emerged as an attractive alternative to submerged fermentation $(\mathrm{SmF})$ (Virupakshi et al., 2005; Roopesh et al., 2006). Although SSF has several advantages over submerged fermentation which include lower wastewater output, reduced energy requirements, simpler fermentation media, easier aeration, reduced bacterial contamination etc. (Pandey et al., 2000). SSF is defined as any fermentation process performed on a non-soluble material that acts both as physical support and source of nutrients in absence of free-flowing liquid (Raimbault, 1980; Sato and Sudo, 1999; Singhania et al., 2010). The low moisture content means that fermentation can only be carried out by a limited number of microorganisms, mainly yeasts and fungi, although some bacteria have also been used (Mitchell, 2000). The solid matrix could be either the source of nutrients or simply support impregnated by the proper nutrients that allow the development of the microorganisms (Thomas et al., 2013). SSF resembles the natural habitat of 
microorganisms and is, therefore, preferred choice for microorganisms to grow and produce useful value-added products. So, fungi have been considered to be the organisms most adapted to SSF because their hyphae can grow on particle surfaces and penetrate into the interparticle spaces and thereby colonizing solid substrates (Santos et al., 2004).

SSF processes offer potential advantages in bioremediation and biological detoxification of hazardous and toxic compounds such us olive by-products (Kumar and Shamsher, 2012). Therefore, these by-products can be used as a substrate in SSF to produce high value-added metabolites such as enzymes, especially phytases for the feed industry, tannases for the food coffee industry, lipases for the laundry industry and detergents (D'annibale et al., 2006; Leite et al., 2016). The use of olive by-products in SSF processes come up with the reduction of pollution around the olive mill, contributing thereafter to the sustainable development of the olive sector. This study aims to develop an innovative process for the valorization of olive oil wastes (OMWW, OC and olive twigs and leaves (OTL). The process consists of growing isolated fungi strains in the solid substrate. For fermentation, fungus will produce several enzymes with high industrial value.

\section{Materials and Methods}

\section{Samples origin}

Olive mill wastewater (OMWW) and olive cake used in the present study were obtained from olive mills using a three-phase discontinuous process for extraction of olive oil. Samples were taken during the olive growing season (November 2015-March 2016) from different regions in Tunisia namely: Al Krib, Téboursouk, Mornag, Gaâfour, Sfax, Zarzis, Châal, and, Jammel (Figure 1). Then, they have been stored at $4{ }^{\circ} \mathrm{C}$ until analyzed.

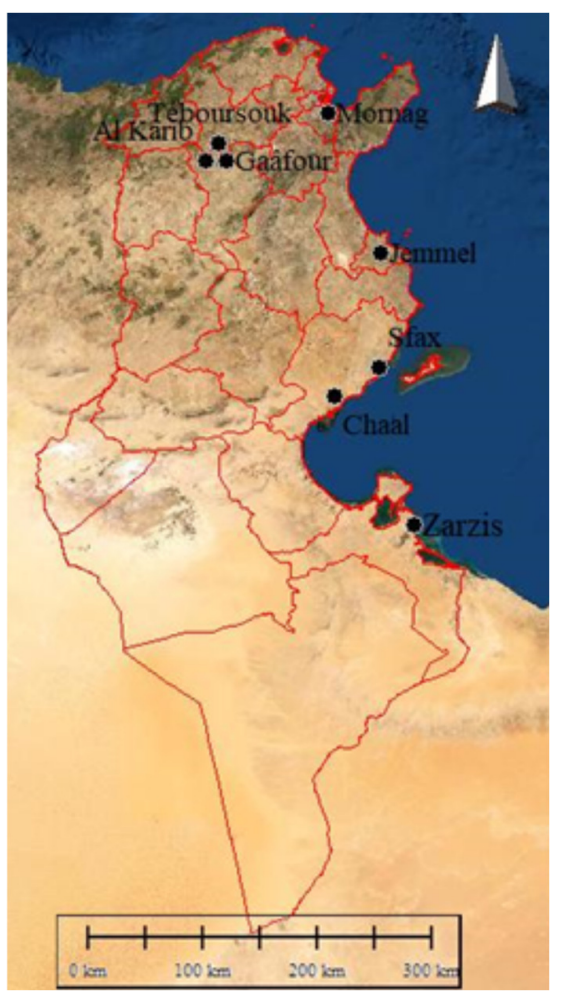

Figure 1. Sampling regions Teboursouk, Al Karib, Gaâfour, Mornag (northest of Tunisia), Jammel (central coast) and Sfax, Châal, Zarzis (southeast of Tunisia). Data source: World Imagery exploited by Global Mapper v18.2 


\section{Fungi isolation and identification}

Isolation of fungi present in OMWW was done by spreading $0.1 \mathrm{ml}$ of different OMWW dilutions on Petri dishes containing $20 \mathrm{ml}$ of Potato Dextrose Agar (Commercial PDA Powder Sigma-Aldrich) contain chloramphenicol $(0.25 \mathrm{~g} / \mathrm{l})$ to avoid bacteria development (Botton et al., 1990). For olive cake samples, three fragments were put directly at three different locations on the surface of Petri dishes. Incubation was done at $30^{\circ} \mathrm{C}$ for $72 \mathrm{~h}$. The obtained fungi from these two types of residues were purified. Pure cultures of fungal strains were kept in tubes with PDA medium inclined and stored at $4{ }^{\circ} \mathrm{C}$, with periodic replications every 3 months. The purified fungi were then subject to microscopic identification basing on the morphological behavior by reference to classical keys reported in the literature (Raper and Fennell, 1965; Barnet and Hunter, 1972; Ainsworth et al., 1973; von Arx, 1974). The morphological identification was followed by a molecular identification, which was performed based firstly on the extraction of the DNA followed by the amplification of the ITS region from the rDNA through polymerase chain reaction (PCR) in a thermocycler (Biometra ${ }^{\circ}$ ), using universal primers ITS1 (5'TCCGTAGGTGAACCTGCGG3') (sense) and ITS4 (5'TCCTCCGCTTATTGATATGC3') (antisense) described by White et al. (1990). The reaction mixture of the PCR having a final volume of $20 \mu \mathrm{l}$ was composed of: $1 \mu \mathrm{l}$ of each primer, Taq buffer $(\times 5)$ with $\mathrm{MgCl} 2$ $(25 \mathrm{mM}), \mathrm{dNTP}(10 \mathrm{mM}), \mathrm{BSA}(0.5 \mathrm{mg} / \mathrm{ml})$, Taq polymerase $(2 \mathrm{U} / \mu \mathrm{l}), 2 \mu \mathrm{l}$ of DNA template and pure water (Attili et al., 1998). The amplification program was run under the following conditions: initial denaturation step of $3 \mathrm{~min}$ at $95^{\circ} \mathrm{C}$, followed by 45 cycles of denaturation at $95^{\circ} \mathrm{C}$ for $60 \mathrm{sec}$, annealing at $54^{\circ} \mathrm{C}$ for $60 \mathrm{sec}$, and extension $72{ }^{\circ} \mathrm{C}$ for $2 \mathrm{~min}$. At the end of the cycles, a final extension was performed at $72^{\circ} \mathrm{C}$ for $7 \mathrm{~min}$ in order to complete the synthesis of unfinished DNA strands (Hassi et al., 2007). Amplification efficiency was confirmed by electrophoresis on $1 \%$ agarose gel. The PCR products were then purified and sequenced using the software Chromas and were compared to those in the 2015 GenBank database of NCBI [http://www.ncbi.nlm.nih.gov/] using the Basic Local Alignment Search Tool (BLAST) algorithm and the 2015 version of the tool Classifier of the Ribosomal Database Project [http://rdp.cme.msu.edu].

\section{Sporulation index and spore production}

Sporulation index of filamentous fungi was determined as described by Roussos (1985) and expressed as the number of spores per gram of substrate utilized in the culture medium. For each isolated strain two to three drops of spore suspension were inoculated into $250 \mathrm{ml}$ Erlenmeyer flasks containing $50 \mathrm{ml}$ of supercooled PDA and incubated at $30{ }^{\circ} \mathrm{C}$ for 5-7 days. The spores are recovered on the surface of the agar medium using an electromagnetic stirrer for about 30 minutes, in a Tween 80 solution (0.01\%). For counting spores, a cell of Malassez was used under optical microscopy. For this purpose, a 1/100 dilution was carried out using water containing tween $80(0.01 \%)$. The count is considered valid when the number of spores is between 10 and 30 per reading field.

\section{Determination of apical growth}

The determination of apical growth for each strain was evaluated by measuring the elongation of the mycelium in millimeters per hour (Roussos and Raimbault, 1982) from the center of the agar surface of the Petri dish (point of inoculation) to the periphery. This elongation is measured daily using a graduated ruler during 7 days. The apical growth expressed by average speed on $\mathrm{mm} /$ hour was calculated following the formula:

$$
\text { Average speed }=\frac{\mathrm{D} \max / 2}{\mathrm{~T}}
$$

$\mathrm{D}_{\text {max }}$ the diameter in $\mathrm{mm}$ of the last measurement $(\mathrm{mm})$.

$\mathrm{T}$ : time of the last day (hour).

\section{Screening of the enzyme-producing strains}

For tested the potential enzymatic activities, the isolated strains were cultured on agar synthetic culture media containing different substrates (Table 1): casein (protease activity), Tween 80 (lipase activity), starch 
(amylase activity), sucrose (invertase activity), carboxyl methyl cellulose (CMC) (cellulase activity), tannic acid (Tannase activity), and phytic acid (Phytase activity).

Table1. Compositions of culture media containing different carbon sources in $\mathrm{g} / \mathrm{l} \mathrm{H}_{2} \mathrm{O}$

\begin{tabular}{|c|c|c|c|c|c|c|c|c|c|c|c|c|c|c|}
\hline & \multicolumn{14}{|c|}{ Composition of culture media $\left(\mathrm{g} / \mathrm{l} \mathrm{H}_{2} \mathrm{O}\right)$} \\
\hline $\begin{array}{c}\text { Culture } \\
\text { media }\end{array}$ & $\mathrm{CaCl}_{2}$ & $\mathrm{MgSO}_{4}$ & $\mathrm{KH}_{2} \mathrm{PO}_{4}$ & $\mathrm{NaCl}$ & $\left(\mathrm{NH}_{4}\right)_{2} \mathrm{SO}_{4}$ & Agar & Tween & Casein & glucose & Sucrose & Starch & $\mathrm{CMC}$ & TA & PA \\
\hline Tween & 0.48 & 0.38 & 2.47 & 0.32 & 6.6 & 20 & 20 & & & & & & & \\
\hline Casein & 0.48 & 0.38 & 2.47 & 0.32 & 6.6 & 20 & & 10 & & & & & & \\
\hline Glucose & 0.48 & 0.38 & 2.47 & 0.32 & 6.6 & 20 & & & 10 & & & & & \\
\hline Sucrose & 0.48 & 0.38 & 2.47 & 0.32 & 6.6 & 20 & & & & 10 & & & & \\
\hline Starch & 0.48 & 0.38 & 2.47 & 0.32 & 6.6 & 20 & & & & & 10 & & & \\
\hline $\mathrm{CMC}$ & 0.48 & 0.38 & 2.47 & 0.32 & 6.6 & 20 & & & & & & 10 & & \\
\hline TA & 0.48 & 0.38 & 2.47 & 0.32 & 6.6 & 20 & & & & & & & 4 & \\
\hline $\mathrm{PA}$ & 0.48 & 0.38 & 2.47 & 0.32 & 6.6 & 20 & & & & & & & & 1 \\
\hline
\end{tabular}

\section{Revelation of enzymatic activities in solid medium}

Tannase and phytase producing strains were determined by a clear and visible halo on a black background (Brahmbhatt and Modi, 2015). For the protease the colonies with a clear zone formed by the hydrolysis of casein (Ozturkoglu-Budak et al., 2016). The lipolytic activity is indicated by the appearance in agar medium an orange fluorescence halo around the colonies (Geoffry and Achur, 2018). Thus, the presence of the halo marks the hydrolysis zone of the appropriate substrate. For the other enzymes, they were highlighted by the appearance of clear zones around the colonies (Madhav et al., 2011; Ozturkoglu-Budak et al., 2016).

\section{Production of enzymes under solid-state fermentation}

For the production of enzymes under SSF, we selected the five best strains: Trichodrema virens, Fusarium oxysporum, Aspergillus niger, Talaromyces assiutensis and Penicillium toxicarium. Olive cake (OC), olive twigs and leaves (OTL) and OMWW were used as substrate for SSF cultures. The OC and OTL were dried in solar greenhouse with $10 \%(\mathrm{w} / \mathrm{w})$ of moisture retained and then was sieved to provide particle sizes between 0.8 and $2 \mathrm{~mm}$, washed three times with distilled water, adjusted to $50 \%$ moisture with distilled water. The individual ingredients of the substrate were mixed thoroughly by mechanical means to achieve a homogenous mixture and sterilized at $121^{\circ} \mathrm{C}$ for $20 \mathrm{~min}$. The column bioreactor used (Figure 2) was composed by small glass columns, with $4 \mathrm{~cm}$ of diameter and $20 \mathrm{~cm}$ of length, and an effective reaction volume of $250 \mathrm{ml}$. $100 \mathrm{~g}$ of SSF support (30\% OMWW, 40\% OTL and 30\% olive cake) and $100 \mathrm{ml}$ of nutritive solution $\left(\mathrm{KH}_{2} \mathrm{PO}_{4}: 1 \mathrm{~g}, \mathrm{NaNO}_{3}: 1 \mathrm{~g}, \mathrm{MgSO}_{4}: 0.5 \mathrm{~g}, \mathrm{pH}=6\right.$.) were mixed with $100 \mathrm{ml}$ of 2.107 spores $/ \mathrm{g}$ of initial dry matter (Roussos and Raimbault, 1982). The final humidity was about $75 \%$. The column bioreactor was packed with $30 \mathrm{~g}$ of solid culture medium and incubated in a water bath set at temperature of $30{ }^{\circ} \mathrm{C}$ for 5 days. Five columns are used for each strain and were sampled at $0,8,16,24,32$ and $40 \mathrm{~h}$ of fermentation for kinetics determination. Aeration of columns was performed by injecting humid air at a flow rate of $25-30 \mathrm{ml} / \mathrm{min}$ in each column. Non inoculated solid medium incubated in the same conditions was used as a control (without spores).

\section{Measure of dry matter}

The dry matter was determined after drying two grams of fermented product at $105^{\circ} \mathrm{C}$ for $24 \mathrm{~h}$, before and after SSF. 


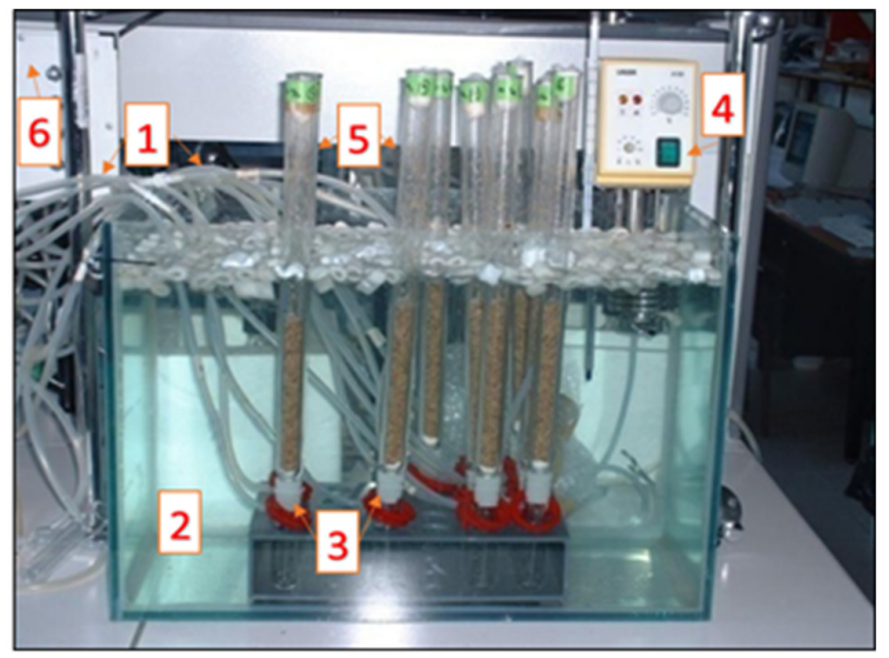

Figure 2. Fermenter used for monitoring the solid-state fermentation

1. Air inlet; 2 . Thermoregulated water bath; 3 . Humidifier; 4. Heating element; 5 . Fermentation columns; 6. Aeration manifold

\section{Enzyme extraction}

The enzymes were extracted by mixing $5 \mathrm{~g}$ of fermented product with $100 \mathrm{ml}$ of distilled water in an Ultra-Turrax IKA T25 homogenizer $\left(19,000 \mathrm{rpm}, 10 \mathrm{~min}, 4^{\circ} \mathrm{C}\right)$. This extract was centrifuged $\left(5000^{*} \mathrm{~g}, 5\right.$ $\min , 4^{\circ} \mathrm{C}$ ) then filtered through a $0.45 \mu \mathrm{m}$ membrane filter (Millipore). The cell-free supernatant was used for enzymes activities assay.

\section{Estimation of reducing sugar}

The reducing sugar (glucose) levels in samples solution were analyzed by 3,5-dinitrosalicylic acid (DNS) assay using glucose as standard, following the method descripted by Miller (1959).

\section{Cellulase assay}

Filter paper assay was used to estimate total cellulase activity in the crude enzyme preparation. A rolled Whatman no. 1 filter paper strip of dimension $1.0 \times 6 \mathrm{~cm}(50 \mathrm{mg})$ was placed into each assay tube. The filter paper strip was saturated with $0.5 \mathrm{ml}$ of Na-citrate buffer $(0.05 \mathrm{M}, \mathrm{pH} 4.8)$ and was equilibrated for $10 \mathrm{~min}$ at $50^{\circ} \mathrm{C}$ in a water bath. A half milliliter of an appropriately diluted (in Na-citrate buffer, $0.05 \mathrm{M} ; \mathrm{pH} 4.8$ ) enzyme was added to the tube and incubated at $50^{\circ} \mathrm{C}$ for $60 \mathrm{~min}$. Appropriate controls were also run along with the test. At the end of the incubation period, tubes were removed from the water bath, and the reaction was stopped by addition of $3 \mathrm{ml}$ of 3,5-dinitrosalicylic acid reagent per tube. The tubes were incubated for $5 \mathrm{~min}$ in a boiling water bath for color development and were cooled rapidly. The reaction mixture was diluted appropriately and was measured against a reagent blank at $575 \mathrm{~nm}$ in a UV-VIS spectrophotometer (Ghose, 1987). The concentration of glucose released by enzyme was determined by comparing against a standard curve constructed similarly with known concentrations of glucose. One unit of cellulase activity was defined as the amount of enzyme required for liberating $1 \mu$ mole of reducing sugar as glucose per minute per ml of fermented juice, under the assay conditions $(\mathrm{U} / \mathrm{ml} / \mathrm{min})$.

\section{Phytase assay}

Enzyme activity was assessed according to the method, descripted by Engelen et al. (2001), using sodium phytate as a substrate. The measure of phytase activity was performed by reacting the enzyme extract with the substrate at $45^{\circ} \mathrm{C}$ for 30 minutes. The reaction was stopped by adding $2.5 \mathrm{ml}$ of trichloroacetic acid (TCA $20 \%$ $\mathrm{w} / \mathrm{v}$ ). For the purpose of measuring the concentration of phosphorus, $5 \mathrm{ml}$ of the colored reagent were added to the reaction mixture. Then, the absorbance was measured by UV-VIS Spectrophotometer at $700 \mathrm{~nm}$. One 
unit of phytase is defined as the amount of enzyme capable of releasing one $\mu$ mole of phosphorus per min and per $\mathrm{ml}$ of fermented extract.

\section{Tannase assay}

Tannase activity was estimated following the method reported by Sharma et al. (2000) and using gallic acid as standard. The absorbance of the pink color developed has been read at $520 \mathrm{~nm}$. The enzyme activity was calculated from the change in absorbance. One unit of tannase activity was defined as the amount of enzyme required to liberate one micromole of gallic acid per minute under defined reaction conditions.

Lipase assay

Lipase activity was measured using p-nitrophenyl octanoate as a substrate (Castilho et al., 2000). This activity was carried out by measuring the increase in the absorbance at $412 \mathrm{~nm}$ due to the release of $\mathrm{p}$ nitrophenol during the hydrolysis of $0.5 \mathrm{mM}$ p-nitrophenyl propionate at $\mathrm{pH}=7$ and $30^{\circ} \mathrm{C}$. To initialize the reaction, $0.1 \mathrm{ml}$ of lipase solution was added to $4.4 \mathrm{ml}$ of substrate solution. One unit of lipase activity was defined as the amount of enzyme liberating one $\mu \mathrm{mol}$ of $\mathrm{p}$-nitrophenol per minute per $\mathrm{ml}$ of fermented juice, under the assay conditions.

All enzymes studied are expressed as units per gram dry substrate (U/gds), and all the experiments were carried out in four repetitions and standard error was calculated.

\section{Statistical analysis}

All experiments were conducted in four repetitions and the results were expressed as media \pm standard error. ANOVA was used for statistical comparisons with p value fixed at 0.05 .

\section{Results and Discussion}

\section{Fungal isolates}

During the 2015-2016 olive oil production campaign, 40 olive mills waste water and olive cake samples were taken from different olive mills. A total of 47 strains of filamentous fungi were isolated and purified from these two residues. Table 2 shows the identified fungus isolated from the various sites; results showed the presence of a very interesting fungal biodiversity. The samples of OMWW and olive cake from the southern region (Zarzis, Sfax and Chaal) contain a higher number of fungi than the northern and Sahel regions. For OMWW, despite their toxic composition, we found a very important number of strains which exceeds the olive cake in all regions. Moreover, the acidic $\mathrm{pH}$ of olive mill wastes may be advantageous for this microbial group to inhibit the growth of bacteria. Aspergillus and Penicillium spp were the most prevalent fungi in OMWW samples and for all studied sites, whereas for olive cake samples a greater heterogeneity was observed, the same results were fund by (Roussos et al., 2006; Aissam et al., 2007). Therefore, the members of the fungal genera Acremonium, Alternaria, Aspergillus, Chalara, Fusarium, Lecythophora, Paecilomyces, Penicillium, Phoma, Phycomyces, Rhinocladiella, and Scopulariopsis have been identified in OMWW disposal ponds, possessing the ability to detoxify olive mill effluents (Millan et al., 2000).

\section{Apical growth and sporulation index of the strains}

The measurement of apical growth indicates the capacity of filamentous fungi for superficial colonization on PDA culture medium. The values provide information's about the kinetics of biomass production and helps better understanding the growth strategy of fungi in their natural habitat. The data of the average apical growth and sporulation index of isolated strains are presented in Table 3. The results obtained indicate that the isolated strains showed a variable apical growth rate and sporulation index at a constant incubation temperature. The comparison of apical growth and sporulation index averages for 
different species revealed an interval ranging from 0.05 to $0.80 \mathrm{~mm} / \mathrm{h}$ and $2.410^{8}$ to $2.3510^{10}$ spores $/ \mathrm{g}$ carbon dry matter respectively. Trichoderma virens, Fusarium oxysporum, Talaromyces trachyspermus, Rhizopus oryzae showed the highest apical growth. Talaromyces trachyspermus, Penicillium griseofulvum, Trichoderma virens, Purpureocillium lilacinum, Aspergillus welwitschiae showed the highest sporulation index.

Table 2. Different genera and species of filamentous fungi isolated from olive mill wastewater and olive cake from different regions of Tunisia

\begin{tabular}{|c|c|c|}
\hline Region/ Origin & OMWW & Olive cake \\
\hline Mornag & $\begin{array}{c}\text { Penicillium crustosum } \\
\text { Geotrichum candidum } \\
\text { Mucor fragilis }\end{array}$ & $\begin{array}{l}\text { Cladosporium cladosporioides } \\
\text { Penicillium expansum }\end{array}$ \\
\hline Teboursouk & $\begin{array}{l}\text { Penicillium polonicum } \\
\text { Penicillium commune } \\
\text { Aspergillus tubingensis }\end{array}$ & $\begin{array}{c}\text { Aspergillus pseudoglaucus } \\
\text { Mucor circinelloides }\end{array}$ \\
\hline Gaâfour & $\begin{array}{c}\text { Trichoderma virens } \\
\text { Penicillium commune } \\
\text { Penicillium crustosum }\end{array}$ & $\begin{array}{l}\text { Alternaria infectoria } \\
\text { Fusarium oxysporum }\end{array}$ \\
\hline Al Karib & $\begin{array}{c}\text { Penicillium expansum } \\
\text { Aspergillus awamori } \\
\text { Aspergillus welwitschiae }\end{array}$ & $\begin{array}{l}\text { Talaromyces trachyspermus } \\
\text { Aureobasidium melanogenum }\end{array}$ \\
\hline Zarzis & $\begin{array}{c}\text { Aspergillus proliferans } \\
\text { Curvularia spicifera } \\
\text { Aspergillus ustus } \\
\text { Aspergillus hiratsukae } \\
\text { Penicillium griseofulvum }\end{array}$ & $\begin{array}{c}\text { Talaromyces assiutensis } \\
\text { Aspergillus niger } \\
\text { Cladosporium cladosporioides }\end{array}$ \\
\hline Sfax & $\begin{array}{c}\text { Aspergillus niger } \\
\text { Penicillium polonicum } \\
\text { Purpureocillium lilacinum } \\
\text { Aspergillus tubingensis }\end{array}$ & Geotrichum candidum \\
\hline Châal & $\begin{array}{c}\text { Penicillium citreonigrum } \\
\text { Aspergillus niger } \\
\text { Aspergillus hiratsukae } \\
\text { Aspergillus awamori } \\
\text { Penicillium toxicarium } \\
\text { Myceliophthora verrucosa } \\
\text { Penicillium commune }\end{array}$ & $\begin{array}{c}\text { Aspergillus awamori } \\
\text { Talaromyces trachyspermus }\end{array}$ \\
\hline Jemmal & $\begin{array}{c}\text { Alternaria alternata } \\
\text { Rhizopus oryzae } \\
\text { Aspergillus niger }\end{array}$ & $\begin{array}{c}\text { Alternaria infectoria } \\
\text { Aspergillus welwitschiae }\end{array}$ \\
\hline
\end{tabular}

Table 3. Fungal colony apical growth on PDA culture medium and sporulation index of different strains incubated at $30^{\circ} \mathrm{C}$ during 7 days

\begin{tabular}{|c|c|c|}
\hline Strains & Apical growth & $\begin{array}{c}\text { Sporulation } \\
\text { index }\end{array}$ \\
\hline Geotrichum candidum & $0.27 \pm 0.041$ & $5.210^{9}$ \\
\hline Aspergillus tubingensis & $0.19 \pm 0.019$ & $9.610^{9}$ \\
\hline Mucor fragilis & $0.36 \pm 0.041$ & $6.210^{9}$ \\
\hline Penicillium crustosum & $0.15 \pm 0.0353$ & $1.8510^{10}$ \\
\hline Alternaria infectoria & $0.15 \pm 0.050$ & $2.410^{9}$ \\
\hline Fusarium oxysporum & $0.62 \pm 0.110$ & $6.210^{9}$ \\
\hline Talaromyces assiutensis & $0.36 \pm 0.038$ & $5.610^{9}$ \\
\hline Aspergillus pseudoglaucus & $0.29 \pm 0.027$ & \\
\hline
\end{tabular}


Zaier H et al. (2021). Not Bot Horti Agrobo 49(1):12125

\begin{tabular}{|c|c|c|}
\hline Penicillium polonicum & $0.05 \pm 0.012$ & $2.410^{9}$ \\
\hline Talaromyces trachyspermus & $0.50 \pm 0.106$ & $2.3510^{10}$ \\
\hline Curvularia spicifera & $0.23 \pm 0.025$ & $2.410^{8}$ \\
\hline Aspergillus ustus & $0.07 \pm 0.014$ & $7.610^{8}$ \\
\hline Aspergillus hiratsukae & $0.37 \pm 0.033$ & $1.610^{10}$ \\
\hline Aspergillus niger & $0.37 \pm 0.054$ & $6.210^{9}$ \\
\hline Alternaria alternata & $0.21 \pm 0.014$ & $3.610^{8}$ \\
\hline Rhizopus oryzae & $0.40 \pm 0.019$ & $6.810^{9}$ \\
\hline Cladosporium cladosporioides & $0.14 \pm 0.013$ & $5.810^{9}$ \\
\hline Penicillium citreonigrum & $0.12 \pm 0.014$ & $2.6410^{9}$ \\
\hline Penicillium commune & $0.12 \pm 0.017$ & $1.610^{10}$ \\
\hline Penicillium toxicarium & $0.10 \pm 0.01$ & $3.410^{9}$ \\
\hline Myceliophthora verrucosa & $0.13 \pm 0.01$ & $3.210^{9}$ \\
\hline Aureobasidium melanogenum & $0.29 \pm 0.046$ & $3.610^{9}$ \\
\hline Penicillium expansum & $0.24 \pm 0.022$ & $2.5610^{9}$ \\
\hline Aspergillus awamori & $0.33 \pm 0.052$ & $1.210^{9}$ \\
\hline Aspergillus proliferans & $0.16 \pm 0.014$ & $2.410^{9}$ \\
\hline Penicillium griseofulvum & $0.30 \pm 0.056$ & $2.310^{10}$ \\
\hline Trichoderma virens & $0.775 \pm 0.109$ & $1.610^{10}$ \\
\hline Aspergillus welwitschiae & $0.60 \pm 0.127$ & $1.510^{10}$ \\
\hline Purpureocillium lilacinum & $0.30 \pm 0.024$ & $1.910^{10}$ \\
\hline Mucor circinelloides & $0.25 \pm 0.036$ & $2.410^{9}$ \\
\hline
\end{tabular}

Data are mean $(\mathrm{n}=4)$

\section{Screening of the enzyme-producing strains}

The screening of the hydrolytic enzyme activities on agar media of the isolated strain was performed by the nutritional study. Thus, this nutrient study reflects the ability of these strains to develop on a specified substrate as well as the involvement of the enzymatic system on the degradation and hydrolysis of these substrates. Therefore, growth on a starch-based medium as the unique carbon source involves the secretion of amylases, for the sucrose, phytic acid, tannic acid, Tween 80 and carboxyl methyl cellulose (CMC), the enzymes involved are invertases, phytases, tannase, lipases (or esterase) and cellulases respectively. Generally, microorganism screening techniques for the production of enzymes are performed using shaken liquid media. Therefore; the implementation of these techniques is cumbersome considering the large number of strains to be tested. Hence, agar medium culture was first used for esterase detection by Hankin and Anagnostakis, (1975). Figure 3 shows the percentage of strains degrading the different substrates. According to the results obtained, we can be noted that starch, sucrose, glucose, casein and carboxyl methyl cellulose have been used by all the strains, while tannic acid is the least used by the strains with a percentage of $53 \%$.

The measurement of the apical growth of different species according to different carbon sources (Table 4) showed that all fungi can degrade a variety of substrates at $30^{\circ} \mathrm{C}$. On average all strains use glucose, sucrose, casein and starch, suggesting that these species can produce the extracellular proteases and amylases. According to Calvo et al. (2002), the simple compounds such as glucose, fructose, sucrose and sorbitol as the unique carbon source generally allow good growth and sporulation. Our results showed that $T$. virens can be considered the best strain in view of the good apical growth on all mediums, so it is able to use all substrates. It can be noted also that the apical growth varies according to the species and even according to the strain, the same results was fund by Lamrani et al. (2006) which have shown that the use of different substrates depends on the production of the enzyme degrading the corresponding substrate. The results obtained showed that the isolated strains are able to hydrolyze and assimilate several carbon sources due to their own enzyme production such as amylase, phytase, protease, cellulase on agar plate synthetic culture media at $30^{\circ} \mathrm{C}$ 


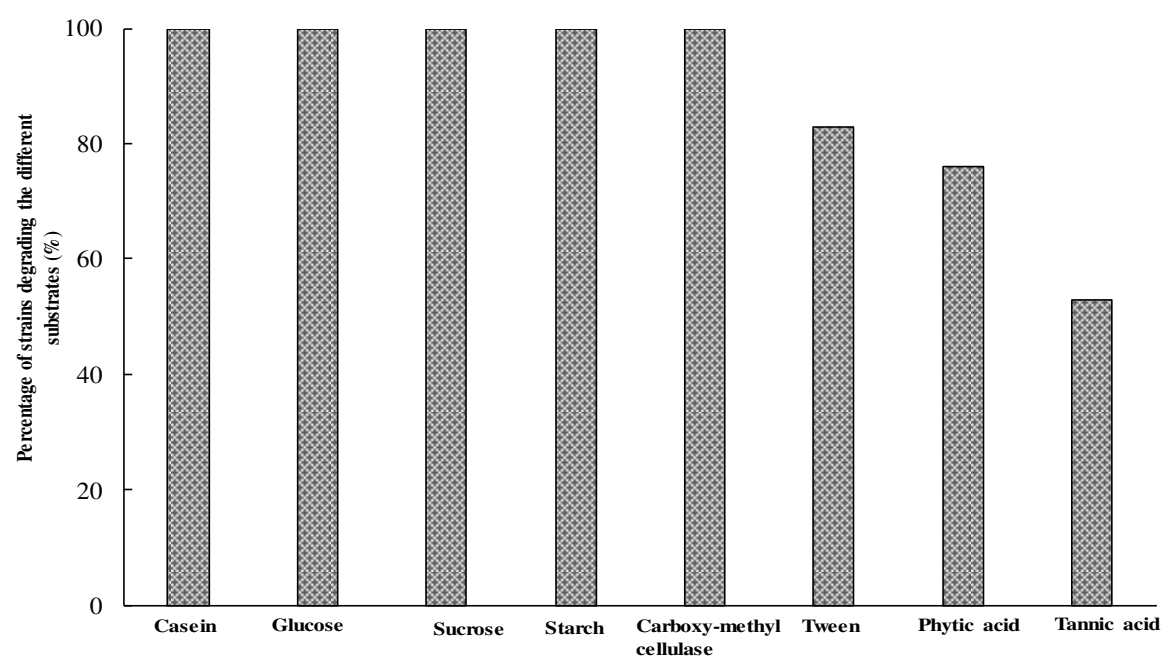

Figure 3. Percentage of selected strains able to grow on different carbon sources

Table 4. The apical growth $(\mathrm{mm} / \mathrm{h})$ of the fungal colonies cultivated on different culture media and incubated at $30^{\circ} \mathrm{C}$ during 7 days

\begin{tabular}{|c|c|c|c|c|c|c|c|c|}
\hline Strains & Tween & Casein & Glucose & Sucrose & Starch & $\begin{array}{l}\text { Carboxy-methyl } \\
\text { cellulose }\end{array}$ & Phytic acid & Tannic acid \\
\hline Penicillium expansum & $0.34 \pm 0.013$ & $0.29 \pm 0.008$ & $0.33 \pm 0.017$ & $0.27 \pm 0.017$ & $0.13 \pm 0.017$ & $0.2 \pm 0.005$ & 0 & 0 \\
\hline Geotrichum candidum & $0.31 \pm 0.037$ & $0.35 \pm 0.022$ & $0.37 \pm 0.017$ & $0.33 \pm 0.005$ & $0.17 \pm 0.017$ & $0.54 \pm 0.053$ & $0.23 \pm 0.022$ & 0 \\
\hline Aspergillus niger & $0.17 \pm 0.008$ & $0.23 \pm 0.017$ & $0.33 \pm 0.008$ & $0.34 \pm 0.017$ & $0.20 \pm 0.017$ & $1.6 \pm 0.163$ & $0.27 \pm 0.026$ & $0.31 \pm 0.033$ \\
\hline Penicillium crustosum & $0.36 \pm 0.013$ & $0.31 \pm 0.010$ & $0.25 \pm 0.026$ & $0.31 \pm 0.017$ & $0.14 \pm 0.017$ & $1.15 \pm 0.125$ & 0 & 0 \\
\hline Alternaria infectoria & $0.16 \pm 0.016$ & $0.26 \pm 0.022$ & $0.22 \pm 0.016$ & $0.24 \pm 0.016$ & $0.19 \pm 0.016$ & $0.4 \pm 0.007$ & 0 & $0.27 \pm 0.016$ \\
\hline Mucor fragilis & $0.20 \pm 0.008$ & $0.32 \pm 0.017$ & $0.30 \pm 0.008$ & $0.36 \pm 0.017$ & $0.32 \pm 0.026$ & $0.75 \pm 0.085$ & $0.34 \pm 0.022$ & 0 \\
\hline Aspergillus pseudoglaucus & $0.17 \pm 0.016$ & $0.22 \pm 0.016$ & $0.19 \pm 0.005$ & $0.22 \pm 0.017$ & $0.17 \pm 0.013$ & $0.7 \pm 0.129$ & $0.18 \pm 0.017$ & 0 \\
\hline Talaromyces assiutensis & $0.18 \pm 0.016$ & $0.28 \pm 0.016$ & $0.33 \pm 0.016$ & $0.34 \pm 0.016$ & $0.12 \pm 0.016$ & $0.55 \pm 0.112$ & $0.15 \pm 0.022$ & $0.35 \pm 0.036$ \\
\hline Curvularia spicifera & 0 & $0.25 \pm 0.016$ & $0.18 \pm 0.008$ & $0.22 \pm 0.007$ & $0.12 \pm 0.014$ & $0.24 \pm 0.016$ & 0 & 0 \\
\hline Aspergillus ustus & 0 & $0.25 \pm 0.014$ & $0.25 \pm 0.022$ & $0.25 \pm 0.025$ & $0.16 \pm 0.007$ & $1.3 \pm 0.158$ & 0 & $0.26 \pm 0.022$ \\
\hline Trichoderma virens & $0.41 \pm 0.036$ & $0.41 \pm 0.032$ & $0.41 \pm 0.007$ & $0.48 \pm 0.016$ & $0.20 \pm 0.007$ & $1.9 \pm 0.158$ & $0.19 \pm 0.05$ & $0.25 \pm 0.022$ \\
\hline Aspergillus awamori & $0.26 \pm 0.007$ & $0.15 \pm 0.016$ & $0.16 \pm 0.016$ & $0.15 \pm 0.007$ & $0.26 \pm 0.016$ & $0.4 \pm 0.064$ & $0.52 \pm 0.022$ & 0 \\
\hline Alternaria alternata & $0.17 \pm 0.014$ & $0.11 \pm 0.016$ & $0.13 \pm 0.007$ & $0.12 \pm 0.016$ & $0.18 \pm 0.026$ & $0.61 \pm 0.026$ & $0.28 \pm 0.026$ & 0 \\
\hline Rhizopus oryzae & 0 & $0.15 \pm 0.007$ & $0.3 \pm 0.007$ & $0.32 \pm 0.016$ & $0.12 \pm 0.016$ & $0.81 \pm 0.064$ & 0 & $0.26 \pm 0.032$ \\
\hline Cladosporium cladosporioides & 0 & $0.25 \pm 0.007$ & $0.21 \pm 0.016$ & $0.23 \pm 0.016$ & $0.13 \pm 0.016$ & $0.2 \pm 0.07$ & 0 & $0.24 \pm 0.016$ \\
\hline Penicillium citreonigrum & $0.41 \pm 0.014$ & $0.25 \pm 0.016$ & $0.25 \pm 0.016$ & $0.21 \pm 0.016$ & $0.25 \pm 0.016$ & $0.6 \pm 0.072$ & $0.34 \pm 0.038$ & $0.27 \pm 0.032$ \\
\hline Penicillium commune & $0.18 \pm 0.022$ & $0.41 \pm 0.041$ & $0.19 \pm 0.007$ & $0.19 \pm 0.016$ & $0.14 \pm 0.007$ & $0.45 \pm 0.041$ & $0.15 \pm 0.028$ & $0.52 \pm 0.058$ \\
\hline Fusarium oxysporum & $0.2 \pm 0.016$ & $0.3 \pm 0.071$ & $0.19 \pm 0.025$ & $0.21 \pm 0.007$ & $0.15 \pm 0.016$ & $0.7 \pm 0.125$ & $0.25 \pm 0.029$ & $0.16 \pm 0.051$ \\
\hline Myceliophthora verrucosa & $0.17 \pm 0.025$ & $0.12 \pm 0.017$ & $0.12 \pm 0.017$ & $0.11 \pm 0.017$ & $0.19 \pm 0.005$ & $0.57 \pm 0.112$ & $0.17 \pm 0.042$ & 0 \\
\hline Aspergillus tubingensis & $0.11 \pm 0.007$ & $0.25 \pm 0.016$ & $0.18 \pm 0.007$ & $0.22 \pm 0.016$ & $0.11 \pm 0.007$ & $0.4 \pm 0.007$ & $0.10 \pm 0.038$ & 0 \\
\hline Penicillium polonicum & $0.22 \pm 0.016$ & $0.16 \pm 0.007$ & $0.15 \pm 0.016$ & $0.16 \pm 0.016$ & $0.19 \pm 0.025$ & $0.5 \pm 0.079$ & $0.2 \pm 0.038$ & 0 \\
\hline Talaromyces trachyspermus & $0.11 \pm 0.007$ & $0.09 \pm 0.016$ & $0.11 \pm 0.016$ & $0.01 \pm 0.007$ & $0.14 \pm 0.016$ & $0.4 \pm 0.03$ & $0.13 \pm 0.016$ & $0.08 \pm 0.016$ \\
\hline Asperillus hiratsukae & $0.41 \pm 0.025$ & $0.25 \pm 0.016$ & $0.25 \pm 0.025$ & $0.21 \pm 0.016$ & $0.25 \pm 0.016$ & $1.25 \pm 0.112$ & $0.41 \pm 0.016$ & $0.27 \pm 0.016$ \\
\hline Penicillium toxicarium & $0.18 \pm 0.007$ & $0.45 \pm 0.038$ & $0.33 \pm 0.016$ & $0.18 \pm 0.007$ & $0.20 \pm 0.016$ & $1.08 \pm 0.166$ & $0.21 \pm 0.016$ & $0.41 \pm 0.015$ \\
\hline Aureobasidium melanogenum & $0.20 \pm 0.0016$ & $0.45 \pm 0.029$ & $0.22 \pm 0.016$ & $0.15 \pm 0.007$ & $0.23 \pm 0.007$ & $1.1 \pm 0.158$ & $0.17 \pm 0.016$ & $0.41 \pm 0.035$ \\
\hline Aspergillus proliferans & $0.15 \pm 0.016$ & $0.25 \pm 0.016$ & $0.28 \pm 0.016$ & $0.28 \pm 0.014$ & $0.14 \pm 0.014$ & $0.76 \pm 0.032$ & $0.18 \pm 0.016$ & $0.25 \pm 0.029$ \\
\hline Penicillium griseofulvum & $0.11 \pm 0.007$ & $0.25 \pm 0.035$ & $0.18 \pm 0.014$ & $0.22 \pm 0.014$ & $0.11 \pm 0.007$ & $0.6 \pm 0.079$ & $0.10 \pm 0.007$ & $0.13 \pm 0.016$ \\
\hline Aspergillus welwitschiae & $0.22 \pm 0.016$ & $0.28 \pm 0.013$ & $0.29 \pm 0.009$ & $0.25 \pm 0.005$ & $0.18 \pm 0.008$ & $0.42 \pm 0.017$ & $0.21 \pm 0.013$ & $0.31 \pm 0.022$ \\
\hline Purpureocillium lilacinum & $0.20 \pm 0.022$ & $0.45 \pm 0.057$ & $0.22 \pm 0.016$ & $0.15 \pm 0.016$ & $0.23 \pm 0.016$ & $1.1 \pm 0.158$ & $0.17 \pm 0.025$ & $0.41 \pm 0.014$ \\
\hline Mucor circinelloides & 0 & $0.26 \pm 0.022$ & $0.19 \pm 0.014$ & $0.21 \pm 0.016$ & $0.14 \pm 0.007$ & $0.35 \pm 0.079$ & $0.22 \pm 0.016$ & 0 \\
\hline
\end{tabular}

Data are mean $(\mathrm{n}=4)$.

\section{Enzymes activity under solid-state fermentation}

After screening the strains grown on agar plate media containing different substrates, the five best strains were selected for the SSF study: Trichoderma virens, Fusarium oxysporum, Aspergillus niger, Talaromyces assiutensis, and Penicillium toxicarium. The choice of these strains is due to their high sporulation index and apical growth on all the media's which implies they are able to hydrolyze and assimilate the different substrates. According to Roussos (1985) and Saucedo-Castaneda (1991) the inoculum in solid-state fermentation processes it is very important in order to select strains with the highest apical growth rates and sporulation index. Based on these screening results we have studied the highlighting of the production of cellulase, phytase, tannase and lipases in solid-state fermentation by these selected strains. Thus, the research concerning the 
production of enzymes in solid-state fermentation remains very limited compared to other fermentation processes, in particular that in liquid medium.

\section{Cellulase activity}

The results of cellulase activity produced by selected strains are presented in Figure 4 a. The cellulase concentration was calculated from the standard curve as $\mathrm{mg}$ of cellulase per $\mathrm{ml}$ of test samples.

Figure $4 \mathrm{a}$ showed that all the strains showed maximum cellulase activity at $24 \mathrm{~h}$ of culture and after the cellulosic activity gradually disappears. Therefore, during the experimentation, the strains tested showed varied cellulase activity. This concentration ranged between 3.83 and $14.55 \mathrm{U} / \mathrm{gds}$. Our study demonstrated the ability to produce enzyme activity varied from strain to strain. Among the five strains, Trichodrema virens and Aspergillus niger have a significantly better ability to produce cellulase activity during the experimentation with a concentration of 14.55 and $9.92 \mathrm{U} / \mathrm{gds}$ respectively at $24 \mathrm{~h}$. Our results are in agreement with those found by Berne et al. (2013) who showed that cellulase activity for Trichoderma sp at SSF that varied from 11 to 50 $\mathrm{U} / \mathrm{gds}$. Reports in the literature suggest that Trichoderma reesei has the strongest cellulose-degrading activity (Penttila et al., 1986; Tomme et al., 1988). Meanwhile, a wide range of Aspergillus sps and Penicillium sps have been identified to possess all components of cellulases complex (de Vries and Visser, 2001; Jahangeer et al., 2005). In addition, Mirzaakhmedov et al. (2007) have shown that the most active producer of cellulolytic enzymes was Aspergillus terreus compared to Penicillium tigrinus, Penicillium ostreatus.

\section{Lipase activity}

Lipases activity of the selected strains were presented in Figure $4 \mathrm{~b}$. According to the results found, the strains showed appreciable differences in their lipolytic activity. This concentration ranged between 19.21 and $33.56 \mathrm{U} / \mathrm{gds}$. We have noticed that the maximum of lipase activity has been recorded for all fungi after $24 \mathrm{~h}$ of culture. Once the maximum lipase production has been reached, the lipase activity decreases gradually. This could be explained either by the presence of proteases in the medium capable of hydrolyzing the lipases or by the thermal instability of the lipolytic enzymes. Therefore, Trichoderma virens showed the highest lipase activity than other strains at $24 \mathrm{~h}(33.56 \mathrm{U} / \mathrm{gds})$ suggesting a good adaptation of this strain to the experimental conditions. This is in accordance with Toscano et al. (2013) who reported that Trichoderma harzianum exhibited elevated extracellular lipase activity (71.3 U/gds) in SSF. However, Aspergillus niger (24.55 U/gds) and Penicillium toxicarium (22.69 U/gds) have shown a moderate lipase activity, while Talaromyces assiutensis (19.21 U/g gds) and Fusarium oxysporum (20.10 U/gds) have lowest lipase activity. In addition, our results are in agreement with those of Gombert et al. (1999) and Falcony et al. (2006), who reported that lipase enzyme produced by fungi, could be enhanced under SSF. Thus, several lipase producing fungal strains have been used for lipase production by SSF which include Penicillium restrictum (Gombert et al., 1999), Aspergillus niger (Kamini et al., 1998; Mahadik et al., 2002), and Rhizopus oligosporus (ul-Haq et al., 2002), Rhizopus delemer (Christen et al., 1998) and Aspergillus oryzae (Kumar and Ray, 2014).

\section{Phytases activity}

Figure 4.c illustrate the phytase activity of selected strain. According to the results, all strains showed significant phytase activity which were ranged between $45.90 \mathrm{U} / \mathrm{gds}$ and $32.55 \mathrm{U} / \mathrm{gds}$ for Trichoderma virens and Aspergillus niger respectively. The phytase activity for all strains began after $8 \mathrm{~h}$ of incubation to reach their maximum after $24 \mathrm{~h}$, then they disappear gradually. Therefore, the phytase activity produced by all the strains is generally attributed to the optimization of initial parameters of the culture in SSF (Initial humidity, pH, aeration rate, etc..). In the literature, it is reported that several filamentous as well thermophilic fungi (Thermoascus aurantiacus, Aspergillus fumigatus, Myceliophthora thermophila, etc...) than mesophilic (A. niger, A. ficuum, etc.) are phytase producers (Mitchell et al., 1997; Liu et al., 1999; Nampoothiri et al., 2004). According to Hassouni et al. (2006 a), it is very important to optimize SSF culture parameters for high-activity phytase production. 

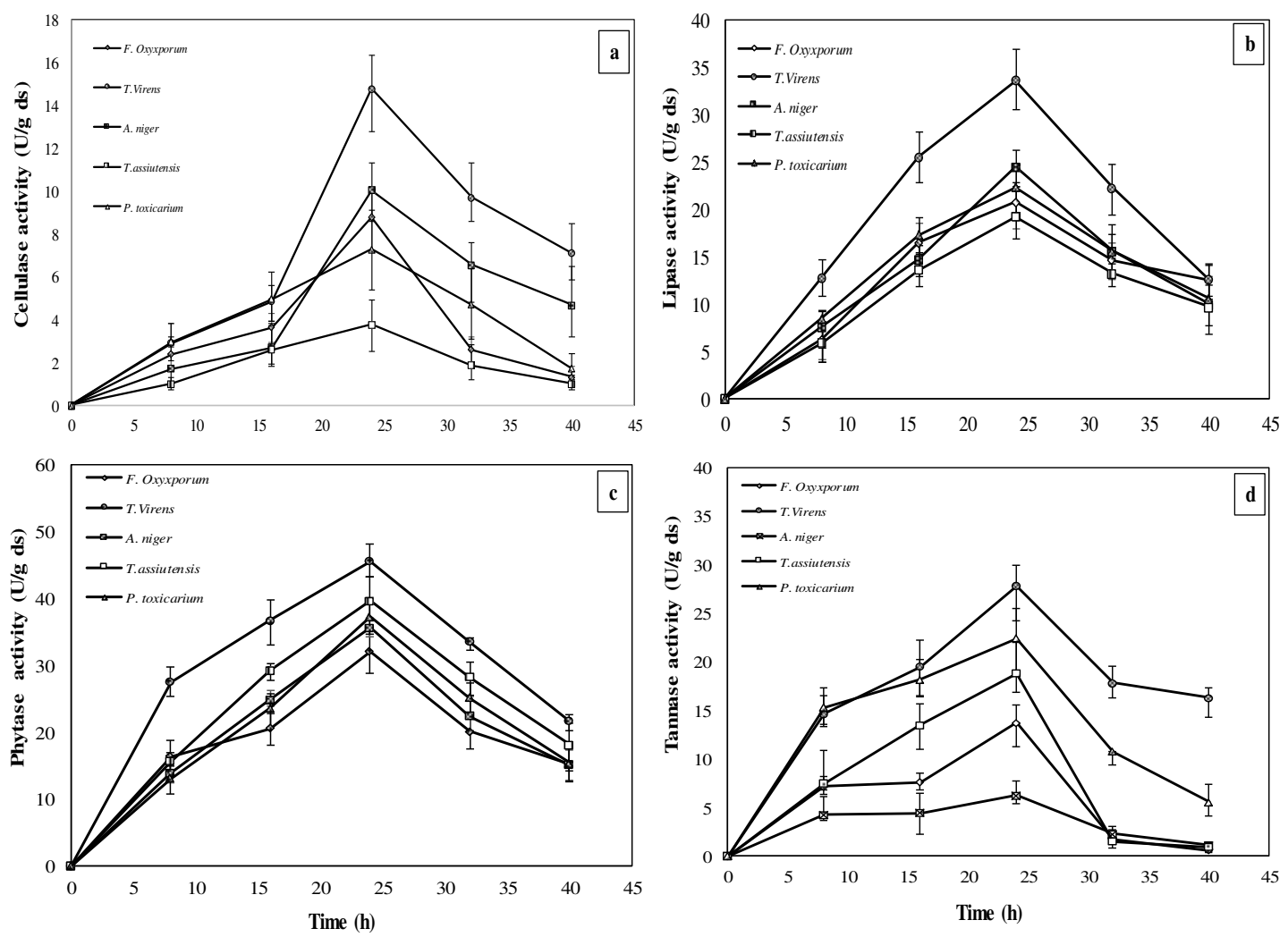

Figure 4. Time course of cellulase (a), lipase (b), phytase (c) and tannase (d) activities from selected strain Data are mean $(n=4)$

These authors showed that, for the same strain, the phytases activity produced is 3.5 times higher after optimization of the SSF culture parameters than that obtained before optimization, and 2.5 times for the reference strain (A. ficuum). Thus, the best condition obtained, was the parameters used in our study which are: $\mathrm{pH}=6$, an initial humidity of $75 \%$ and aeration rate $20-25 \mathrm{ml} / \mathrm{min} /$ column. In addition, the initial $\mathrm{pH}$ is a key parameter for the production of phytases and an initial $\mathrm{pH}=6$ is clearly favorable for high phytase production. According to this study, the phytase activity for $T$. virens reaches $45.90 \mathrm{U} / \mathrm{gds}$ at $\mathrm{pH}=6$. This is in agreement with the result of Hassouni et al. (2006 a) who tested phytase activity in M. thermophila at different $\mathrm{pH}$ values and showed that the strain produced a high phytases activity $(180 \mathrm{U} / \mathrm{gds})$ after 36 hours of SSF at $\mathrm{pH}=6$. Gargova and Sariyska (2003) and Kim et al. (1999) also, found that the initial pH of the culture medium influences phytase production in Aspergillus spp. Additionally, the nature of the carbon and the nitrogen sources influence the production of phytases (Ramachandran et al., 2005; Roopesh et al., 2006). So, the glucose in the nutrient solution used by the strains as a carbon source for the SSF culture makes it possible to have a maximum enzymatic activity. Glucose is a simple source of carbon that is, easily, assimilated by microorganisms. It allows having a lot of biomass needed for the dephosphorylation of phytic acid. Accordingly; glucose, starch or sucrose are widely used for the production of phytases, especially, in $M$. thermophila (Mitchell et al., 1997) and Rhizopus oligosporus (Ramachandran et al., 2005).

\section{Tannase activity}

The results of Tannase activity produced by selected strains are presented in Figure $4 \mathrm{~d}$. According to the obtained results, the tannase activity showed the same appearance as the other enzymatic activity (cellulase, lipase and phytase). Thus, the activity of tannase for all the strains start at $8 \mathrm{~h}$ to reach is maximum at $24 \mathrm{~h}$ and after decreased gradually. According to Kar et al. (1999) this decrease in production of enzyme activity may be 
due to accumulation of end product which hampers tannase production or may be due to accumulation of toxic metabolites secreted during fermentation. Our results showed that the tannase activity varied between strain, some being much more efficient than others. Among the five strains, Trichoderma virens have a significantly better ability to produce cellulase activity with a concentration of $27.93 \mathrm{U} / \mathrm{gds}$ at $24 \mathrm{~h}$ while Aspergillus niger (6.22 U/gds) have lowest lipase activity. Moreover, the SSF monitoring showed that the tannase activity of these strains is extremely fast using this culture technique compared with other techniques. Lamrani et al. (2006) tested the tannase activity in three Moroccan strains ( $R$ h pusillus, A. fumigatus, A. fumigatus) and a Mexican strain (A. fumigatus) which has been used as a reference strain. So, the four strains produced very similar amounts ranging from 16.89 to $18.7 \mathrm{U} / \mathrm{gds}$ for the reference strain after 24 hours of incubation. Comparative studies of Lekha and Lonsane (1997) on the production of tannases by $A$. niger reveal that SSF production is 2.5 to 4.8 times higher than in liquid-state fermentation. The fermentation time to reach maximum production in SSF is 3 days whereas it is 6 days in liquid-state fermentation. In addition, the enzyme is totally extracellular in SSF and partially intracellular in liquid-state fermentation. Finally, the tannase produced in SSF is much more thermostable compared to that produced in liquid-state fermentation.

\section{Conclusions}

In the present study, the five strains tested showed high activity of tannase, cellulases, phytase and lipases. However, $T$. virens showed the highest enzymatic activities compared to the other strains which confirmed the results found of screening on agar plate synthetic culture media containing different substrate. Moreover, the monitoring of SSF has shown that the metabolic activity of these strains is extremely rapid using olive byproducts as substrate. Thus, for the five strains, the biosynthesis of the enzymes starts from 8 hours of SSF culture, and once the maximum production of these enzymes has been reached after 24 hours of culture, these enzymatic activities gradually decrease. This study showed that SSF has many advantages for the production of enzymes useful in biotechnology. Thus, a large number of commercial enzymes (cellulases, tannase, phytase, lipases) are produced by SSF and they have all been successful in the world market. From the results found, our strains collection is very interesting and contains a variety of strains capable to produce a variety of enzyme. The strains tested after their culture in SSF present promising results which will have to be better exploited. In particular, by optimizing the production conditions in SSF in a more advanced research work in order to transfer to the production of enzymes on a pilot scale. This study also opens new perspectives for the use of strain in SSF, this also for the production of enzymes, by the useful fungi, usable for the valorization of the agricultural by-products.

\section{Authors' Contributions}

All authors contributed to the study conception and design. Material preparation, data collection and analysis were performed by $\mathrm{ZH}$, and MS. The first draft of the manuscript was written by $\mathrm{ZH}$; Writing - review and editing: MS; Conceptualization: RS; Supervision: AR and all authors commented on previous versions of the manuscript. All authors read and approved the final manuscript.

\section{Acknowledgements}

This work is a part of the project "Recherche de molécules d'intérêt à partir des sous-produits de l'olivier par la technique de la fermentation en milieu solide (FMS)" funded by the Tunisian Institution of Agricultural Research and Higher Education (IRESA). The authors want to express their gratitude to the Environmental, 
Biotechnology and Chemometrics Team at Aix Marseille University for their technical support during this study.

\section{Conflict of Interests}

The authors declare that there are no conflicts of interest related to this article.

\section{References}

Adrio JL, Demain AL (2014). Microbial enzymes: tools for biotechnological processes. Biomolecules 4:117-139. https://doi.org/10.3390/biom4010117

Ainsworth GC, Sparrow FK, Sussman AS (1973). The fungi. Academic Press, New York, pp 504-621.

Aissam H, Penninckx M, Benlemlih M (2007). Reduction of phenolics content and COD in olive oil mill wastewaters by indigenous yeasts and fungi. World Journal of Microbiology and Biotechnology 23:1203-1208. https://doi.org/10.1007/s11274-007-9348-0

Altieri R, Esposito A (2008). Olive orchard amended with two experimental olive mill wastes mixtures: Effects on soil organic carbon, plant growth and yield. Bioresource Technology 99:8390-8393. https://doi.org/10.1016/j.biortech.2008.02.048

Arvanitoyannis IS, Kassaveti A, Stefanatos S (2007). Olive oil waste treatment: a comparative and critical presentation of methods, advantages and disadvantages. Critical Reviews in Food Science and Nutrition 47:187-229. https://doi.org/10.1080/10408390600695300

Attili DS, de Hoog Sybren AA, Kleiner P (1998). RDNA-RFLP and ITS I sequencing of species of the genus Fonsecaea, agents of chromoblastomycosis. Medical Mycology 36:219-225. https://doi.org/10.1080/02681219880000331

Baffi MA, Romo-Sanchez S, Ubeda-Iranzo J (2012). Fungi isolated from olive ecosystems and screening of their potential biotechnological use. New Biotechnology 29:451-456. https://doi.org/10.1016/j.nbt.2011.05.004

Barnett HL, Hunter BB (1972). Illustrated genera of imperfect fungi. 3rd edition, Burgess Publishing Co pp 273.

Benyahia N, Zein K (2003). Analyse des problèmes de l'industrie de l'huile d'olive et solutions récemment développées. [A special look at the waste problems of the olive oil industry and the latest viable solutions]. Contribution spéciale de Sustainable Business Associates (Suisse) à SESEC II pp 2-7.

Berne C, Carboué Q, Fabresse C (2013). Etat physiologique et virulence du champignon filamenteux Trichoderma harzianum. Master. Faculté des sciences. Et techniques Saint Jerome. Aix-Marseille Université pp 20.

Botton B, Breton A, Févre, M, Gauthier S (1990). Les Moisissures Utiles et Nuisibles: Importance Industrielle., $2^{\text {nd }}$ Ed. Masson pp 426.

Brahmbhatt D, Modi HA (2015). Comparative Studies on methods of tannase assay. International Journal for Research in Applied Science and Engineering Technology (IJRASET) 3:715-720.

Calvo AM, Wilson RA, Bok JW, Keller NP (2002). Relationship between secondary metabolism and fungal development. Microbiology and Molecular Biology Reviews 66:447-459. https://doi.org/10.1128/MMBR.66.3.447-459.2002

Castilho LR, Polato CMS, Baruque EA, Sant'anna GL, Freire DMG (2000). Economic analysis of lipase production by Penicillium restrictum in solid-state and submerged fermentations. Biochemical Engineering Journal 4:239-247.

Cegarra J, Alburquerque JA, Gonzálvez J, Tortosa G, Chaw D (2006). Effects of the forced ventilation on composting of a solid olive-mill by-product ("alperujo") managed by mechanical turning. Waste Management 26:1377-1383.

Christen P, Angeles N, Farres A, Revah S (1998). Comparison of production of lipase from Rhizopus delemar by submerged and solid-state fermentation. J. Orstom pp 321-334.

D'Annibale A, Sermanni GG, Federici F, Petruccioli M (2006). Olive-mill wastewaters: a promising substrate for microbial lipase production. Bioresource Technology 97:1828-1833.

de Vries RP, Visser J (2001). Aspergillus enzymes involved in degradation of plant cell wall polysaccharides. Microbiology and Molecular Biology Reviews 65:497-522. https://doi.org/10.1128/MMBR.65.4.497-522.2001

Engelen AJ, Heeft FC, Randsdorp PHG, Somers WAC, Schaefer J, van der Vat BJ (2001). Determination of phytase activity in feed by a colorimetric enzymatic method: collaborative interlaboratory study. Journal of AOAC International 84:629-633. 
Falony G, Armas JC, Julio C, Mendoza D, Jose L, Hermandez M (2006). Production of extracellular lipase from Aspergillus niger by solid-state fermentation. Food Technology and Biotechnology 44:235-240.

Fernández-Bolaños J, Guillermo R, Rocío R, Guillén R, Jiménez A (2006). Extraction of interesting organic compounds from olive oil waste. Grasas Y Aceites 57:95-106. https://doi.org/10.3989/gya.2006.v57.i1.25

Gargova S, Sariyska M (2003). Effect of culture conditions on the biosynthesis of Aspergillus niger phytase and acid phosphatase. Enzyme and Microbial Technology 32:231-235. https://doi.org/10.1016/S0141-0229(02)00247-8

Geoffry K, Achur RN (2018). Screening and production of lipase from fungal organisms. Biocatalysis and Agricultural Biotechnology 14: 241-253. https://doi.org/10.1016/J.BCAB.2018.03.009

Ghose TK (1987). Measurement of cellulase activities. Pure and Applied Chemistry 59:257-268. https://doi.org/10.1351/pac198759020257

Gombert AK, Pinto AL, Castilho LR, Freire DMG (1999). Lipase production by Penicillium restrictum in solid-state fermentation using babassu oil cake as substrate. Process Biochemistry 35:85-89. https://doi.org/10.1385/abab:84-86:1-9:1137

Hafidi M, Amir S, Revel JC (2005). Structural characterization of olive mill waste-water after aerobic digestion using elemental analysis, FTIR and 13C NMR. Process Biochemistry 40:2615-2622. https://doi.org/10.1016/j.procbio.2004.06.062

Hankin L, Anagnostakis SL (1975). The Use of solid media for detection of enzyme production by fungi. Mycologia 67:597-607. https://doi.org/10.2307/3758395

Hassi M, Haggoud A, EL Mzibri M, Ibnsouda S, Houari A, Iraqui M (2007). Isolation and identification of a staphylococcal strain with an anti-mycobacterial activity and study of its mode of action. Annals of Microbiology 57:651-656. https://doi.org/10.1007/BF03175368

Hassouni H, Ismaili-Alaoui M, Perraud-Gaime I, Augur C, Roussos S (2006a). Effect of culture media and fermentation parameters on phytase production by the thermophilic fungus Myceliophthora thermophila in solid state fermentation. Micologia Aplicada International 18:29-36.

Hassouni H, Ismaili-Alaoui M, Lamrani K, Perraud-Gaime I, Augur C, Roussos S (2006 b). Spore germination of filamentous fungi in solid state fermentation under different culture conditions. Micologia Aplicada International 19:1-9.

Jahangeer S, Khan N, Sohali M, Shahzad S, Ahmad A, Khan S (2005). Screening and characterization of fungal cellulases isolated from the native environmental source. Pakistan Journal of Botany 37:739-748.

Kamini NR, Mala JGS, Puvanakrishnan D (1998). Lipase production from Aspergillus niger by solid-state fermentation using gingelly oil cake. Process Biochemistry 33:505-511. https://doi.org/10.1016/S0032-9592(98)00005-3

Kar B, Banerjee R, Bhattacharya BC (1999). Microbial production of gallic acid by modified solid-state fermentation. The Journal of Industrial Microbiology and Biotechnology 23:173-177. https://doi.org/10.1038/sj.jim.2900713

Kim DS, Godber JS, Kim SW (1999). Culture conditions for a new phytase producing fungus. Biotechnology Letters 21:1077-1081. https://doi.org/10.1023/A:1005696829168

Kumar A, Shamsher SK (2012). Lipase production in solid-state fermentation (SSF): recent developments and biotechnological applications. Dynamic Biochemistry, Process Biotechnology and Molecular Biology 6:13-27.

Kumar DS, Ray S (2014). Fungal lipase production by solid state fermentation-an overview. Journal of Analytical and Bioanalytical Techniques 6:1-10.

Lamrani K (2009). Etude de la biodiversité des moisissures nuisibles et utiles isolées à partir des Maâsra du Maroc. Thèse de doctorat d'état, pp 154-155.

Lamrani K, Ismaili-Alaoui M, Cheheb M, Kammas N, Iraqi-Houssaini L, Hassouni H, ... Roussos S (2006). Distribution écologique des champignons filamenteux thermophiles isolés à partir des principales Maâsra du Maroc. In: Biotechnologies et qualité des produits de l'olivier dans le bassin méditerranéen. Actes Editions, Rabat, pp 293306.

Leite P, Salgado JM, Venâncio A (2016). Ultrasounds pretreatment of olive pomace to improve xylanase and cellulase production by solid-state fermentation. Bioresource Technology 214:737-746. https://doi.org/10.1016/j.biortech.2016.05.028

Lekha PK, Lonsane BK (1997). Production and application of tanin acyl hydrolase: State of the art. Advances in Applied Microbiology 44:215-260. https://doi.org/10.1016/s0065-2164(08)70463-5

Liu BL, Rafiq A, Tzeng YM, Rob A (1998). The induction and characterization of phytase and beyond. Enzyme and Microbial Technology 22:415-424. https://doi.org/10.1016/S0141-0229(97)00210-X 
Lobedanz S, Damhus T, Borchert TV, Hansen TT, Lund H, Lai W, ... Kirk O (2016). Enzymes in industrial biotechnology. Kirk-Othmer Encyclopedia of Chemical Technology 1-73. https://doi.org/10.1002/0471238961.0914042114090512.a01.pub3

Madhav K, Verma S, Tanta R (2011). Isolation of amylase producing Bacillus species, from soil sample of different regions in Dehradun and to check the effect of $\mathrm{pH}$ and temperature on their amylase activity. Journal of Pharmaceutical and Biomedical Sciences 12:1-8.

Mahadik ND, Puntambekar US, Bastawde KB, khire JM, Gokhale DV (2002). Production of acidic lipase by Aspergillus niger in solid state fermentation. Process Biochemistry 38:715-721.

Maheshwari R, Bharadwaj G, Bhat MK (2000). Thermophilic fungi: their physiology and enzymes. Microbiology and Molecular Biology Reviews 64:461-88. https://doi.org/10.1128/mmbr.64.3.461-488.2000

Millán B, Lucas R, Robles A, García T, Álvarez de Cienfuegos G, Gálvez A (2000). A study on the microbiotica from olivemill wastewater (OMW) disposal lagoons, with emphasis on filamentous fungi and their biodegradative potential. Microbiological Research 155:143-147. https://doi.org/10.1016/s0944-5013(00)80027-0

Miller GL (1959). Use of dinitrosalicylic acid reagent for determination of reducing sugar. Analytical Chemistry 31:426428. https://doi.org/10.1021/ac60147a030

Mirzaakhmedov SY, Ziyavitdinov ZF, Akhmedova ZR, Saliev AB, Ruzmetova DT, Ashurov K, ... Lametti S (2007). Isolation, purification, and enzymatic activity of cellulase components of the fungus Aspergillus terreus. Chemistry of Natural Compounds 43:594-597.

Mitchell DB, Vogel K, Weimann BJ, Pasamontes L, van Loon AP (1997). The phytase subfamily of histidine acid phosphatases: isolation of genes for two novel phytases from the fungi Aspergillus terreus and Myceliophtora thermophila. Microbiology 143:245-252. https://doi.org/10.1099/00221287-143-1-245

Morillo JA, Antizar-Ladislao B, Monteoliva-Sánchez M, Ramos-Cormenzana A, Russell NJ (2009). Bioremediation and biovalorisation of olive-mill wastes. Applied Microbiology and Biotechnology 82:25-39. https://doi.org/10.1007/s00253-008-1801-y

Nampoothiri K, Madhavan T, Jino G, Krishnan R, Szakacs G, Nagy V, ... Pandey A (2004). Thermostable phytase production by Thermoascus aurantiacus in submerged fermentation. Applied Biochemistry and Biotechnology 118:205-214. https://doi.org/10.1385/ABAB:118:1-3:205

Nefzaoui A (1995). Feeding value of Mediterranean ruminant feed resources. Advanced course Syria, March pp 12-23.

Niaounakis M, Halvadakis CP (2006). Physical processes. In: Olive Processing Waste Management: Literature Review and Patent Survey ( $2^{\text {nd }}$ Edn), Elsevier, Amsterdam, the Netherlands pp 107-113.

Nigam PN (2013). Microbial Enzymes with special characteristics for biotechnological applications. Biomolecules 3:597611. https://doi.org/10.3390/biom3030597

Office National de l'Huile (ONH) (2016). http://www.onh.com.tn/index.php/fr/2016-05-23-14-44-46/la-production.

Office National de l'Huile (ONH) (2018). http://www.onh.com.tn/index.php/fr/commercialisation/positionnementsur-le-marche-mondial.

Ozturkoglu-Budak S, Wiebenga A, Bron PA, de Vries RP (2016). Protease and lipase activities of fungal and bacterial strains derived from an artisanal raw ewe's milk cheese. International Journal of Food Microbiology 237:17-27. https://doi.org/10.1016/j.ijfoodmicro.2016.08.007

Gianni P, Keskos D, Macris BJ, Christakopoulos P (2003). Production of cellulolytic and xylanolytic enzymes by Fusarium oxysporum on corn stover in solid state fermentation. Industrial Crops and Products 18:37-45. https://doi.org/10.1016/S0926-6690(03)00018-9

Penttila M, Lehtovaara P, Nevalainen H, Bhikhabhai R, Knowles J (1986). Homology between cellulase genes of Trichoderma reesei: complete nucleotide sequence of the endoglucanase I gene. Gene 45:253-263. https://doi.org/10.1016/0378-1119(86)90023-5

Raimbault M (1980). Fermentation en milieu solide. Croissance de champignons filamenteux sur substrat amylacé. Thèse d'Etat. Université Paul Sabatier, Toulouse, France pp 291.

Ramachandran S, Roopesh K, Nampoothiri KM, Szakas G, Pandey A (2005). Mixed substrate fermentation for the production of phytase by Rhizopus spp. Using oilcakes as substrates. Process Biochemystry 40:1749-1754. https://doi.org/10.1016/j.procbio.2004.06.040

Ramond JB, Welz PJ, Tuffin MI, Burton SG, Cowan DA (2013). Assessment of temporal and spatial evolution of bacterial communities in a biological sand filter mesocosm treating winery wastewater. Journal of Applied Microbiology 115:91-101. https://doi.org/10.1111/jam.12203

Raper KB, Fennel DI (1977). The Genus Aspergillus. Krieger Publishing company. New York pp 686. 
Robinson PK (2015). Enzymes: principles and biotechnological applications. Essays Biochemistry 59:1-41. https://doi.org/10.1042/bse0590001

Rodrìguez Couto S, Sanromán M (2006). Application of solid-state fermentation to food industry. Journal of Food Engineering 76:291-302. https://doi.org/10.1016/j.jfoodeng.2005.05.022

Romo-Sánchez S, Alves-Baffi M, Arévalo-Villena M, Úbeda-Iranzo J, Briones-Pérez A (2010). Yeast biodiversity from oleic ecosystems: study of their biotechnological properties. Food Microbiology 27:487-492. https://doi.org/10.1016/j.fm.2009.12.009

Roopesh K, Ramachandran S, Nampoothiri KM, Szakacs G, Pandey A (2006). Comparison of phytase production on wheat bran and oil cakes in solid-state fermentation by Mucor racemosus. Bioresource Technology 97:506-511. https://doi.org/10.1016/j.biortech.2005.02.046

Roussos S (1985). Croissance de Trichoderma harzianum par fermentation en milieu solide: Physiologie, sporulation et production de cellulase. Thèse d'Etat, Université de Provence, Marseille, pp 193.

Roussos S, Raimbault M (1982). Hydrolyse de la cellulose par les moisissures: Screening des souches cellulolytiques. Annales de Microbiologie 133:455-464.

Roussos S, Zaouia N, Salih G, Tantaoui-Elaraki A, Lamrani K, Cheheb M, ... Ismaili-Alaoui M (2006). Characterization of filamentous fungi isolated from Moroccan olive and olive cake: Toxinogenic potential of Aspergillus strains. Molecular Nutrition and Food Research 50:500-506. https://doi.org/10.1002/mnfr.200600005

Sánchez S, Demain A (2017). Useful microbial enzymes-an introduction. In book: Biotechnology of Microbial Enzymes. https://doi.org/10.1016/B978-0-12-803725-6.00001-7

Santos MM, Rosa AS, Dal'boit S, Mitchell DA, Kriger N (2004). Thermal denaturation: is solid state fermentation really a good technology for the production of enzymes? Bioresource Technolgy 93:261-268. https://doi.org/10.1016/j.biortech.2003.11.007

Sato K, Sudo S (1999). Small-scale solid-state fermentation. In: Demain AL, Davies JE (Eds.). Manual of industrial microbiology and biotechnology. $2^{\text {ed }}$ pp 61-79.

Saucedo-Castaneda G (1991). Contrôle du métabolisme de Schwanniomyces castellii cultivé sur support solide. Thèse de doctorat, Université de Montpellier II pp 212.

Sharma S, Bhat TK, Dawra RK (2000). A spectrophotometric method for assay of tannase using rhodanine. Analytical Biochemistry 279:85-89. https://doi.org/10.1006/abio.1999.4405

Singhania RR, Sukumaran RK, Patel AK, Larroche C, Pandey A (2010). Advancement and comparative profiles in the production technologies using solid-state and submerged fermentation for microbial cellulases. Enzyme and Microbial Technology 46:541-549. https://doi.org/10.1016/j.enzmictec.2010.03.010

Thomas L, Larroche C, Pandey A (2013). Current developments in solid-state fermentation. Biochemical Engineering Journal 81:146-161.

Tomme P, VanTilbeurgh H, Pettersson G, VanDamme J, Vandekerchhove J, Knowles J, ... Claeyssens M (1988). Studies of the cellulolytic system of Trichoderma reesei QM 9414. Analysis of domain function in two cellobiohydrolases by limited proteolysis. European Journal of Biochemistry 170:575-581. https://doi.org/10.1111/j.14321033.1988.tb13736.x

Idrees S, Rajoka MI (2002). Production of lipases by Rhizopus oligosporous by solid-state fermentation. Process Biochemistry 37:637-641. https://doi.org/10.1016/S0032-9592(01)00252-7

Virupakshi S, Gireesh Babu K, Gaikwad SR, Naik GR (2005). Production of a xylanolytic enzyme by a thermoalkaliphilic Bacillus sp. JB-99 in solid state fermentation. Process Biochemistry 40:431-435. https://doi.org/10.1016/J.PROCBIO.2004.01.027

von Arx JA (1974). The genera of fungi sporulating in pure culture. $2^{\text {nd }}$ Cramer: Vaduz pp 315.

White TJ, Bruns T, Lee S, Taylor J (1990). Amplification and direct sequencing of fungal ribosomal RNA genes for phylogenetics. In: Innis MA, Gelfand DH, Sninsky JJ, White TJ, (Eds). PCR Protocols: a guide to methods and applications. Academic Press, New York, pp 315-322. 
OPEN ACCESS

(c) (2)

The journal offers free, immediate, and unrestricted access to peer-reviewed research and scholarly work. Users are allowed to read, download, copy, distribute, print, search, or link to the full texts of the articles, or use them for any other lawful purpose, without asking prior permission from the publisher or the author.

License - Articles published in Notulae Botanicae Horti Agrobotanici Cluj-Napoca are Open-Access, distributed under the terms and conditions of the Creative Commons Attribution (CC BY 4.0) License. (C) Articles by the authors; UASVM, Cluj-Napoca, Romania. The journal allows the author(s) to hold the copyright/to retain publishing rights without restriction. 